\title{
TARP Beneficiaries and Their Lending Patterns During the Financial Crisis
}

\author{
Silvio Contessi and Johanna L. Francis
}

\begin{abstract}
This paper provides a systematic analysis of the lending performance of U.S. commercial banks and savings institutions that received financial support through the Capital Purchase Program (CPP) established in October 2008. The authors combine U.S. Treasury data on recipients of the CPP with quarterly financial data for the entire population of depository institutions to reconstruct aggregate lending and gross credit flows (expansion and contraction). CPP institutions experienced a less severe lending contraction than non-CPP institutions for all types of loans and bank asset levels. The authors find no evidence of unusual reallocation of lending across depository institutions. (JEL E44, E51, G21)
\end{abstract}

Federal Reserve Banks of St. Louis Review, March/April 2011, 93(2), pp. 105-25.

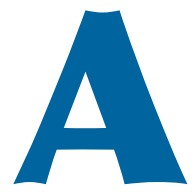

nalyses of disaggregated commercial bank data reveal substantial heterogeneity among groups of banks along various dimensions of activity, including the dynamics of lending. This paper undertakes a systematic analysis of the lending performance of U.S. depository institutions (banks and thrifts, termed DIs hereafter) that distinguishes between two groups: the DIs that received financial support through the Capital Purchase Program (CPP) of the Troubled Asset Relief Program (TARP) of 2008-10 and those that did not receive any assistance through this program (non-CPP).

Analyses of the lending patterns are relevant because the explicitly stated objective of the CPP and other related programs was to slow the lending decline. ${ }^{1}$ Therefore, the objective of our analysis is to identify possible prima facie differences in lending patterns in these two groups of DIs to pave the way for further analysis on the impact of the CPP on lending. The Office of the Special Inspector General for the Troubled Asset Relief Program (SIGTARP, 2009a) scrutinized the lending behavior of nine large financial institutions that received CPP assistance and found a contraction in their lending, suggesting that the CPP program did not deliver what it promised. Our analysis is more extensive-in fact, as extensive as feasible: We study the entire population of U.S. commercial banks and thrifts. We construct a novel dataset based on four sources of data. We

\footnotetext{
1 This objective was clearly stated by Treasury Secretary Geithner in the "Remarks" section introducing the Financial Stability Plan (February 10, 2009): "The capital will come with conditions to help ensure that every dollar of assistance is used to generate a level of lending greater than what would have been possible in the absence of government support." In addition to reducing the impact of the credit contraction, the program was designed to favor the ordered recapitalization of financial institutions, an argument put forth by many commentators and economists (Hoshi and Kashyap, 2010).
} 


\section{Figure 1}

\section{Timeline for Economic Crisis}

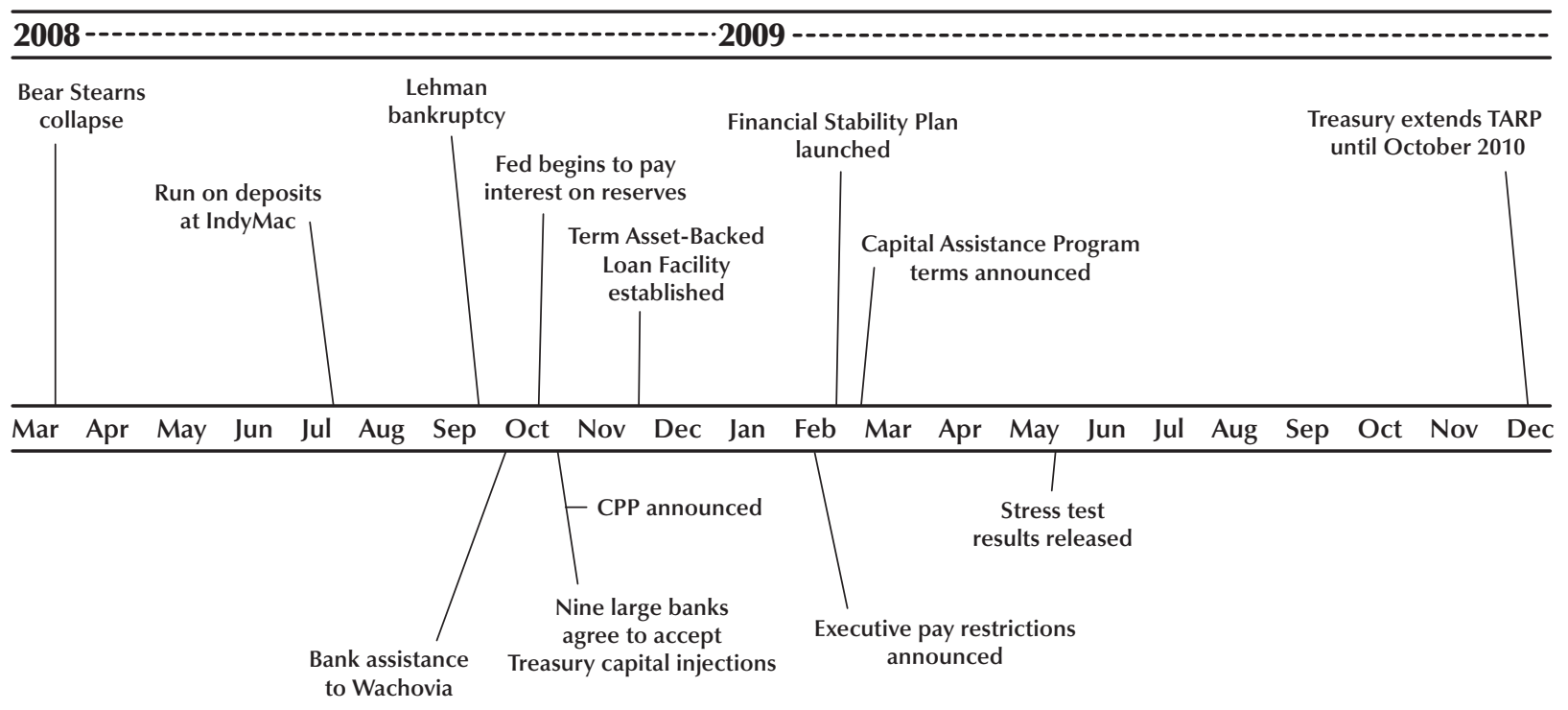

first combine public regulatory data at the level of the individual financial institution-namely, loans of all U.S. commercial banks (through Call Reports [CRs]) and thrifts (through Thrift Financial Reports [TFRs]). ${ }^{2}$ This allows us to use data on cross-mergers and acquisitions to control for situations in which a bank acquires one or more thrifts and vice versa. We then match Treasury data on the CPP disbursement to the CRs and TFRs (summarized in the "Data and Descriptive Statistics" section). Using this dataset we study aggregate and gross credit flows series for U.S. commercial banks and thrifts between 1998:Q1 and 2010:Q2, dividing them into CPP and nonCPP beneficiaries. ${ }^{3}$

We show that the DIs that received CPP assistance exhibited less contraction than non-CPP

2 This type of study has rarely been done thus far, except for Lown, Peristiani, and Robinson (2006) and Avery and Samolyk (2004).

The CRs have been widely used in applied banking research; see, for example, Cebenoyan and Strahan (2004) and Kishana and Opielab (2006).

3 More precisely, the definition of "depository institutions" includes mutual savings banks, savings and loan associations, credit unions, and regulated investment companies. beneficiaries. This is particularly evident for real estate lending and relatively larger institutions. We emphasize that a better performance of CPP beneficiaries may be due to either the fact that the CPP actually slowed the decline in lending or to selection and endogeneity problems that are not addressed here but which we attempt to analyze in related research. We then use gross credit flows (expansion and contraction) to determine whether unusual reallocation of credit occurred across banks during the crisis and find no evidence of this in our data.

\section{THE TARP: AN OVERVIEW}

The TARP is part of the Emergency Economic Stabilization Act signed into law on October 3, 2008. This and other events pertaining to the financial crisis are shown in the timeline of selected events in Figure 1. The initial plan proposed by U.S. Secretary of the Treasury Henry Paulson and Federal Reserve Chairman Ben Bernanke was to allow the U.S. Treasury to purchase or insure up to $\$ 700$ billion of a wide array of "troubled assets" that included not only 
mortgage-backed securities but also "any other financial instrument" on the books of U.S. financial institutions; the plan's objective was to promote stability in the financial system. The initial course of action had to be altered because major complications in pricing these complex assets prevented immediate action at the peak of the financial crisis. On October 14, 2008, the U.S. Treasury established the CPP with the intent to recapitalize banks by purchasing $\$ 250$ billion in preferred shares of stocks in "healthy qualifying financial institutions" (banks, savings associations, bank holding companies [BHCs], and certain savings and loans institutions). The initial $\$ 125$ billion was dispersed to the nine largest banks and the remaining funds were soon made available to other institutions. ${ }^{4}$ The Treasury determined eligibility and allocation of funds after consultation with the appropriate federal banking agency charged with supervision of the applicant. The capital injections were normally achieved by the purchase of senior preferred stocks. In return for its investment, the Treasury received dividend payments and warrants. ${ }^{5}$ The value of the shares bought by the U.S. Treasury was between 1 and 3 percent of the participating institutions' risk-weighted assets, not to exceed $\$ 25$ billion. The Treasury specified the qualifications for preferred shares and dividend payments.

According to the guidelines established by the Treasury, any qualifying financial institution was entitled to apply for CPP assistance. ${ }^{6}$ The applications were submitted to the institution's primary regulator for initial eligibility determination. The federal banking agency then reviewed many financial aspects of the bank, especially

\footnotetext{
4 The nine banks are Bank of America, Bank of New York Mellon, Citigroup, Goldman Sachs, JPMorgan, Morgan Stanley, State Street, Wells Fargo, and Merrill Lynch.

5 The February Report by the Congressional Oversight Panel indicates that for every $\$ 100$ invested, the Treasury received stock and warrants worth only approximately $\$ 66$; see Congressional Oversight Panel (2009), pp. 5-11. The receipt of warrants to purchase common stock was intended to allow the Treasury to gain from potential stock price increases.

${ }^{6}$ Such applications listed guidelines and asked for contact information and information on the amount of shares requested, the sum of the institution's total risk-weighted assets, and a description of any mergers, acquisitions, and capital raising that were currently pending.
}

its CAMELS rating. ${ }^{7}$ The federal banking agency then classified each bank into one of three categories:

Category 1 applications were evaluated by the TARP Investment Committee, composed of senior Treasury officials. The Committee could grant preliminary approval for an application and send it to the assistant secretary for financial stability, who had the final authority to approve the application.

Category 2 applications were sent to the investment committee at the Treasury's Office of Financial Stability. The committee could recommend an application for approval, request more information, or recommend withdrawal. If recommended for approval, the Category 1 process was initiated.

Category 3 applicants were asked to send more information or withdraw their applications.

The settlement stage then began within two business days at which point the transactions were publicly announced, but announcements were not made regarding applicants that did not receive funding. The Treasury website lists details of terms and conditions on the shares, warrants, loans, and so on (for example, dividends, limits, executive compensation, repurchasing, and reporting). ${ }^{8}$ Although the individual financial institutions had to meet certain standards, they were not required to report on the use of funds, a fact that was subsequently widely criticized (see SIGTARP, 2009b).

After May 2009, the program took two somewhat unanticipated turns. First, some financial institutions volunteered to return the capital injection earlier than expected. Accordingly, the Treasury established guidelines for the repayment

\footnotetext{
7 A confidential rating of a bank's overall condition that is based on capital adequacy (C), asset quality (A), management quality (M), earnings (E), liquidity, (L) and sensitivity to market risk (S) hence CAMELS.

8 By December 31, 2009, a few hundred billion dollars of TARP funds had been committed in a total of 12 programs, including the American International Group (AIG) Targeted Investment Program (\$69.8 billion), Legacy Securities Public-Private Investment Program ( $\$ 30$ billion), and the Automotive Industry Financing Program ( $\$ 81.3$ billion).
} 
of the funds through redemption of an institution's preferred stocks and repurchase of the warrants, upon approval by its regulators. Second, the Treasury announced that the application period for publicly held financial institutions to participate in the CPP ended on November 14, 2009, at the same time allowing the beneficiaries of the program to keep the funds if they wished. ${ }^{9}$

SIGTARP (2009a) and Congressional Oversight Panel (2009) provide a more detailed analysis of the TARP funds distributed to other programs. In the next sections, readers are first cautioned to handle lending data with care, and then the construction of the dataset and prima facie differences between CPP and non-CPP DIs are discussed.

\section{Lending Data During the Crisis: Handle Aggregate Data with Care}

Figure 2 shows monthly total loans and leases by commercial banks and their components: real estate loans, individual loans, commercial and industrial (C\&I) loans, and other loans. This measure is part of the H.8 data, which provide weekly aggregate balance-sheet data for commercial banks with a charter in the United States. H.8 data are weekly and monthly estimates based on data reported by a sample (not the entire population) of domestically chartered commercial banks and U.S. branches and agencies of foreign banks. ${ }^{10}$ The 70 banks that make up the top percentile of commercial banks based on total assets represented about 73 percent of the total loans in the 2009:Q1 CRs.

If considered over the past three decades, the series appears to be approximately on trend but

\footnotetext{
9 See "Road to Stability" (www.financialstability.gov/roadtostability/ capitalpurchaseprogram.html) for details.

${ }^{10}$ Footnote 1 of the H.8 releases explains the procedure used to estimate these figures (see www.federalreserve.gov/releases/h8/current/ default.htm). The data for domestically chartered commercial banks and U.S. branches and agencies of foreign banks are estimated by benchmarking weekly data provided by a sample of banks to quarter-end reports of condition (CRs). Large domestically chartered commercial banks are defined as the top 25 domestically chartered commercial banks, ranked by domestic assets as of the previous commercial bank CR to which the H.8 release data have been benchmarked. Because H.8 figures are estimates, they are revised like other data series (e.g., the components of gross domestic product) when more information becomes available.
}

slightly erratic during the recent recession; the total amount of loans and leases remains fairly constant until the end of 2008:Q3, when that amount increases sharply and then declines. Similarly, the consumer loans series exhibits a noticeable increase in the spring of 2010. We later discuss two reasons such data should be handled with extreme care when making inferences about lending dynamics during the crisis.

\section{Accounting for Bank Dynamics}

Among the key provisions of the Financial Services Modernization Act of 1999 (also known as the Gramm-Leach-Bliley Act of 1999) were the removal of financial specialization and the allowance of cross-acquisitions among banks and other financial institutions. When a commercial bank acquires a thrift, an insurance company, or another financial firm, the loans of the target (acquired) company suddenly appear as additional aggregate commercial bank loans even though no real change in credit took place in the economy. A similar increase is observed when a non-bank institution (for example, a credit card company) becomes a commercial bank. We term these institutions, which previously would not have held commercial bank charters, "new" commercial banks.

Several financial entities that would not typically be regulated as banks (such as Merrill Lynch and American Express) acquired charters during the financial crisis because they either applied for a charter or were acquired by regulated commercial banks and thrifts and thus now would file CRs and TFRs. ${ }^{11}$

Many such transactions occurred during the crisis, at times creating an upward shift to the series that should not be interpreted as an increase in lending. As an example, we consider the acquisition of the banking operations of Washington Mutual-a saving institution-by JPMorgan Chase-a commercial bank-on September 25, 2008. Not accounting for the acquisition of

\footnotetext{
${ }^{11}$ Namely, these entities are Goldman Sachs, Morgan Stanley, Merrill Lynch, American Express, CIT Group Inc., Hartford Financial Services, Discover Financial Services, GMAC Financial Services, IB Finance Holding Company, and Protective Life Corporation.
} 


\section{Figure 2}

\section{Aggregate Lending of Commercial Banks (with and without correcting for FAS Nos. 166 and 167)}
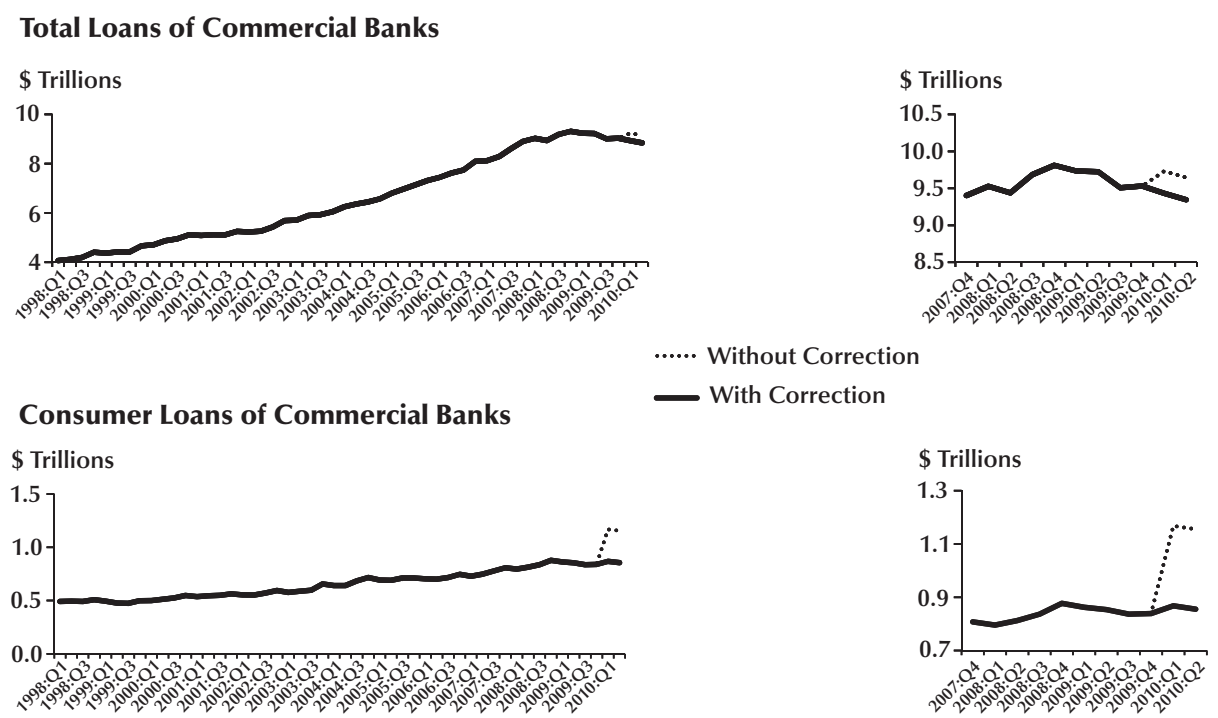

NOTE: FAS, Financial Accounting Statements.

SOURCE: $\mathrm{H} .8$ data.

Washington Mutual by JPMorgan Chase in September 2008 would overestimate the total commercial bank loans in 2008:Q3 because the loans of Washington Mutual-a saving institution-entered the pool of loans of JPMorgan Chase-a bank—at the end of September 2009 and appear as a large expansion of the latter's credit. Our study deals with mergers and acquisitions on a case-by-case basis. Moreover, we eliminate new banks from the study if the lending data for the period before the acquisition of their charter are not available and because their lending portfolios and patterns are significantly different from ordinary banks or thrifts.

\section{Consumer Loans in 2010}

A second example of unusual behavior of a lending series is observed in the consumer loans series in the spring of 2010 (El-Ghazaly and Gopalan, 2010). Aggregate data on consumer loans during March and April 2010 apparently suggest a dramatic expansion in credit to consumers. At first glance, this jump could be interpreted as evidence of banks loosening their credit standards or originating more consumer loans in a recovering economy. While consumer loans did expand relative to the previous months, the impressive increases in March and April 2010 were caused by a change in accounting standards.

In June 2009, the Financial Accounting Standards Board issued two new Financial Accounting Statements (FASs), Nos. 166 and 167, that changed how banks treat off-balance-sheet special-purpose entities (SPEs) and the investments in these entities. ${ }^{12}$ As a result, regulated financial institutions were required to begin consolidating SPEs onto their balance sheets for any

12 Banks and other financial institutions rely on an "originate-todistribute" business model to transfer assets from their balance sheets, bundling risky assets (such as mortgages, credit cards, and auto loans) into securities and then selling them to investors in the secondary market. Selling these assets in the secondary market allows banks to increase servicing revenues and other loan sale income (fees and income associated with collecting and distributing loan payments and other services [e.g., tax payments]) while passing along the credit risk to a larger pool of investors. 
SPEs in which they hold a controlling financial interest. SPEs in which a controlling interest is held must be included in the accounting for riskweighted assets (as Tier 2 capital) for purposes of calculating capital requirements. ${ }^{13}$

As a result of these regulatory changes, assets that had previously been included as off-balancesheet items are now incorporated on the balance sheet to calculate capital requirements. This change affected the total volume of loans and leases reported beginning in 2009:Q4, particularly loans to individuals and other smaller categories of loans. The change in reporting requirements effectively "increased" loans to consumers by approximately $\$ 330$ billion in 2010:Q1. ${ }^{14}$ Information about how these changes were implemented by individual banks and thrifts is not available; thus we can adjust only the aggregate data for the amount of the change and so can report some of our series only until the end of 2009.

\section{DATA AND DESCRIPTIVE STATISTICS}

Our complete dataset aggregates four other datasets. The first two sources for this study are the Consolidated Reports of Condition and Income database (commonly called the Call Reports and the Thrift Reports). Unless otherwise specified, our last data point is the end of June 2010.

\footnotetext{
${ }^{13}$ There is an optional transition period of two financial reporting quarters after the date a banking organization is required to implement FASs 166 and 167, which allows institutions to slowly begin the transfer of such assets to their balance sheets. Beginning on November 9, 2009, banks with fiscal year-ends between November 9 and January 1 were required to begin reporting assets contained in special investment vehicles as on-balance-sheet items and all other banks were required to make the changes beginning January 1, 2010. In addition to the changes in reporting requirements instituted by FASs 166 and 167, on January 28, 2010, federal banking agencies (Office of the Comptroller of the Currency, Board of Governors of the Federal Reserve System, Federal Deposit Insurance Corporation, and the Office of Thrift Supervision) issued a final rule that amended the risk-based capital guidelines established in FASs 166 and 167; the final rule eliminates the exclusion of asset-backed commercial paper programs from riskweighted assets. Banking institutions were permitted a phase-in period for the elimination of this exclusion.

${ }^{14}$ See www.federalreserve.gov/releases/h8/h8notes.htm\#notes $\underline{20100625}$
}

The CRs contain quarterly regulatory information for all banks regulated by the Federal Reserve System, the Federal Deposit Insurance Corporation (FDIC), and the Comptroller of the Currency. The TFRs contain similar information for all thrifts regulated by the Office of Thrift Supervision. In these datasets, DIs report their individual-entity lending activities on a consolidated basis for the entire group of banks or thrifts owned by the reporting entity at the end of each quarter. We use the data available (at the time of this writing) covering the quarters between 1998:Q1 and 2010:Q2. During this period the number of reporting entities in the CRs fell from 10,271 to 7,403 , while the number of reporting entities in the TFRs fell from 1,195 to 753 as a result of bank failures, mergers, and acquisitions. See Aubuchon and Wheelock (2010) for an analysis of recent bank failures.

To account for consolidation, entry, and exit during the sample period, we match the CR and TFR data with the National Information Center's transformation table available from the Board of Governors of the Federal Reserve System. ${ }^{15}$ This matching process allows us to account for problems generated by commercial banks' acquisitions of thrifts and thrifts' acquisitions of banks as mentioned previously. This correction is critical because the Gramm-Leach-Bliley Act removed financial specialization and allowed crossacquisitions between banks and thrifts. We explain our reconciliation of these sources of information in the appendix.

Finally, we omit the new commercial banks, as defined in the previous section, because their lending portfolios and patterns are significantly different from those of ordinary banks or thrifts and we lack comparable data from earlier periods. Once we remove the double counting of loans due to mergers and acquisitions, failures, and new commercial banks in the database, we match the Treasury data on the CPP disbursements to the unbalanced panel created from CRs and TFRs.

\footnotetext{
15 Similar information is publicly available in the Bank Holding Company Data available on the Chicago Fed website (www.chicagofed.org/webpages/banking/financial institution reports/bhc_data.cfm).
} 


\section{Figure 3}

\section{TARP/CPP Disbursements and Repayments (October 2008-December 2009)}

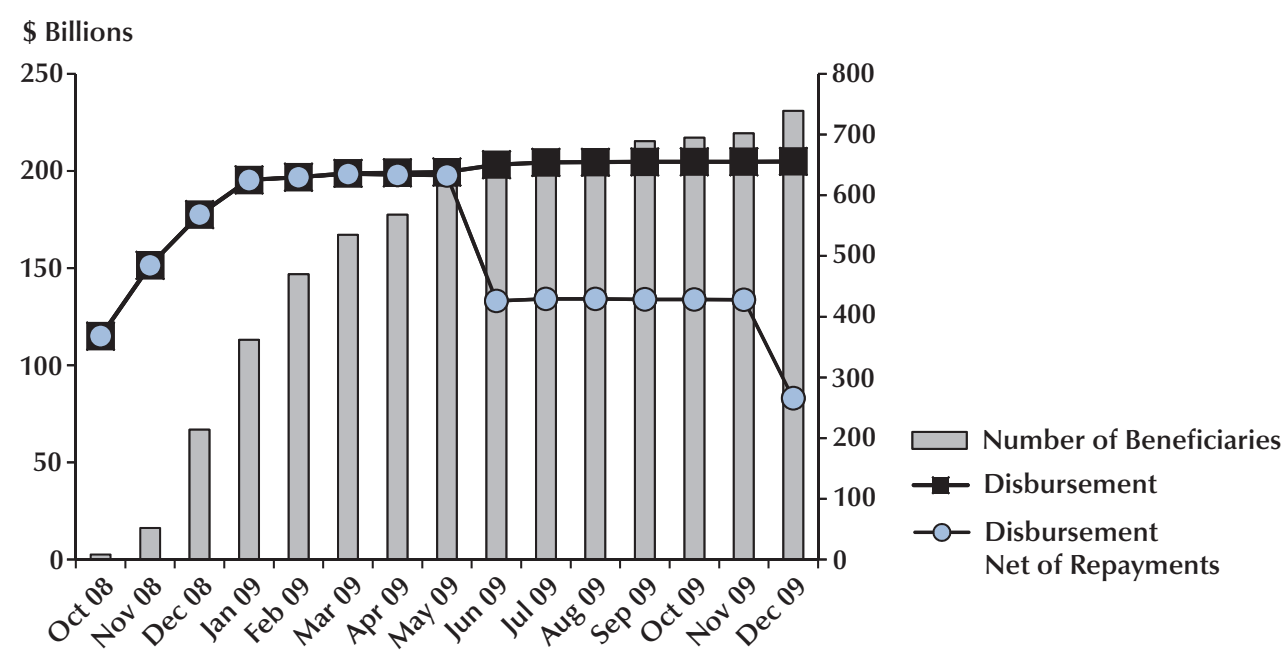

SOURCE: Authors' calculations based on Treasury data.

We describe the salient features of CPP beneficiaries using the non-CPP DIs for comparison. We group institutions using information on the distribution of TARP funds from the TARP Transactions Reports updated weekly by the U.S. Treasury since the program's inception in October 2008. ${ }^{16}$ Figure 3 plots the patterns of monthly disbursements and repayments derived from these data, using the Treasury Transactions Report

${ }^{16}$ The allocation of CPP funds to BHCs instead of individual banks and thrifts has raised some criticism (Coates and Scharfstein, 2009) and creates various issues in our dataset because, unlike the TFRs and the CRs, the TARP Transactions Reports list the BHCs. Therefore, we organized the data as follows. First, we determined the entity identification numbers for all DIs listed to make the TARP information compatible with our CR and TFR information. By using the Competitive Analysis and Structure Source Instrument for Depository Institutions (CASSIDI) database managed by the Federal Reserve Bank of St. Louis and the Federal Financial Institutions Examination Council's institution history database, we determined the set of institutions each BHC controls, BHC by BHC. We organized our data into five categories. If the BHC controls only a single bank or thrift, we match the TARP Transactions Report information with the single bank or thrift's Federal Reserve entity identification number. When the BHC controls several different banks or a mix of banks and thrifts, all of the loans of the individual banks and thrifts are totaled and the group is given the BHC's entity identification number. Additionally, we separated out the funds distributed to large lenders and other beneficiaries that are either nonfinancial institutions (namely, General Motors and Chrysler) or new commercial banks and thrifts. releases. ${ }^{17}$ The figure shows the total number of beneficiaries by month (vertical bars), the total disbursement (squares), and the monthly disbursement net of repayments (circles). Over its first 15 months, the CPP allowed the injection of almost $\$ 205$ billion of capital into approximately 730 financial entities (U.S. Treasury, 2009). ${ }^{18}$ As of December 31, 2009, 71 institutions had redeemed their preferred stocks and about $\$ 83$ billion stayed invested in the remaining beneficiaries. It should be noted that the observational units in the Transactions Reports are financial holdings and not individual banks or thrifts per se. The institutions that received funding under the program could allocate the funds to any of the institutions they control. Therefore, in the remainder of the analysis we reaggregate individual DIs that have a charter (and an entity identification number in

${ }^{17}$ See the relevant files on the Financial Stability website (www.financialstability.gov/). The Congressional Oversight Panel (2009) reported some difficulties in confirming the exact value of the Treasury disbursements using these figures.

18 The latest available TARP Transactions Report was accessed on January 31, 2010, and contains information for the period ending January 13, 2010. See www.financialstability.gov/latest/ reportsanddocs.html for details. 


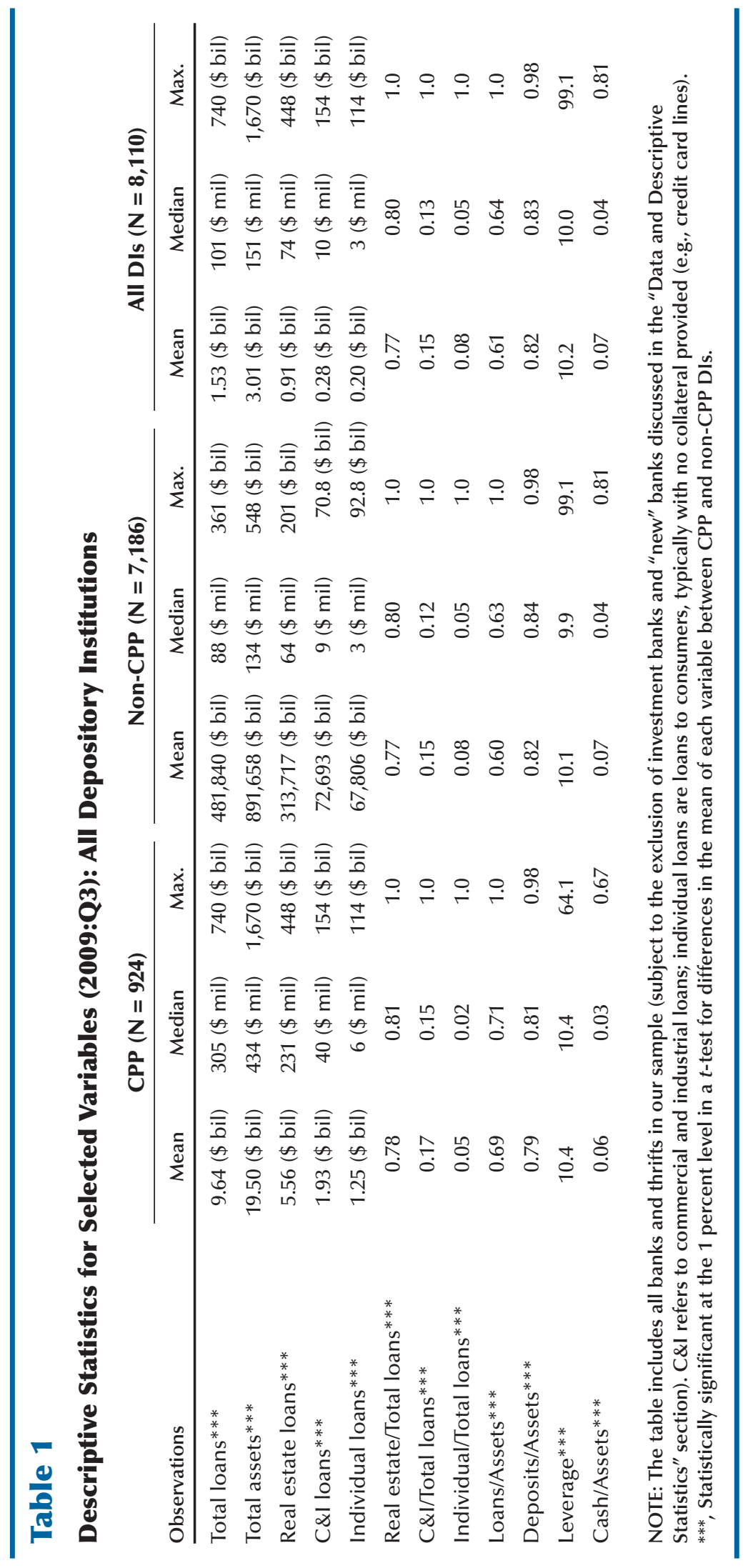




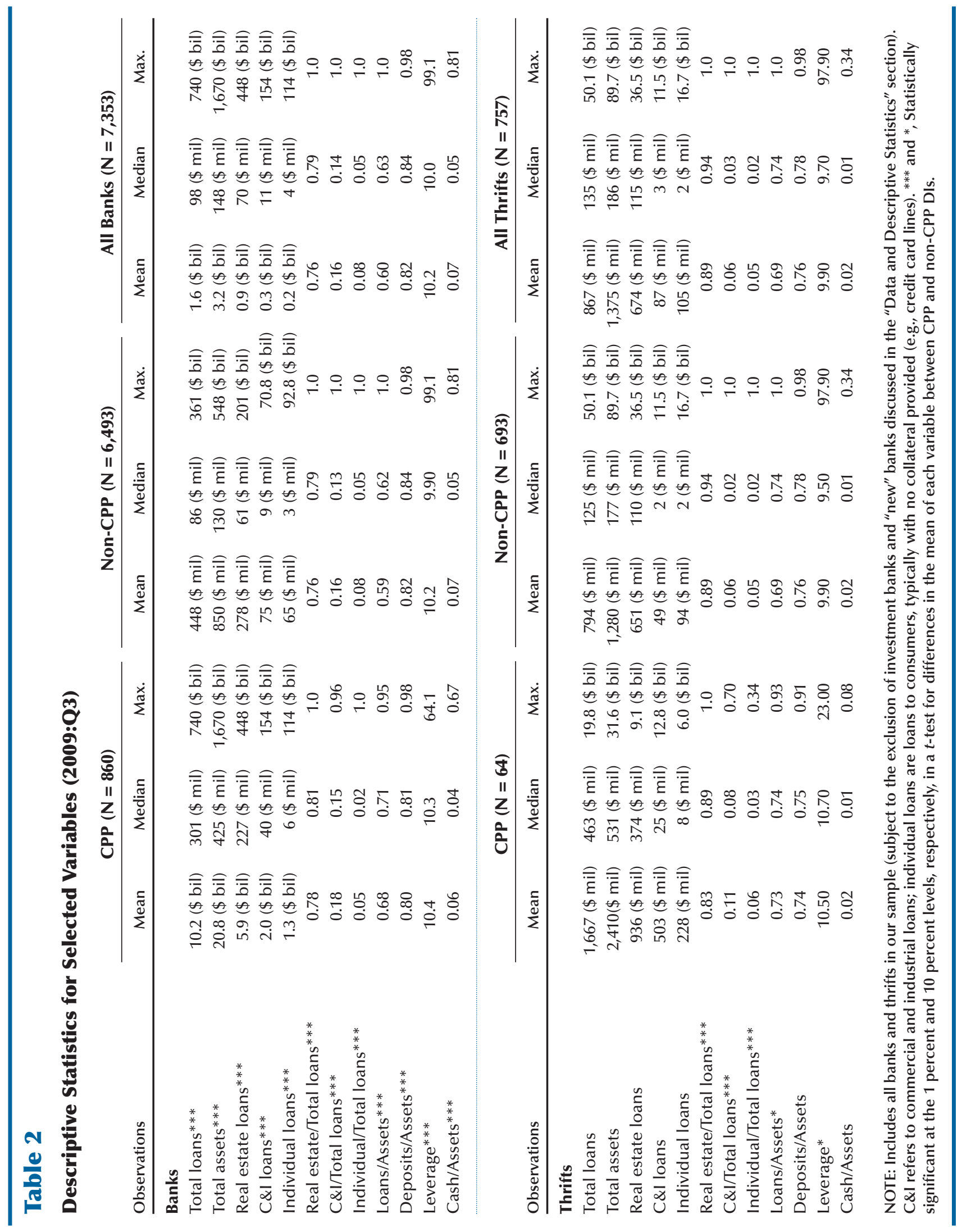


Figure 4

Kernel Size Distribution of Deposits-to-Assets Ratios, Log Asset, and Log Total Loans of CPP and non-CPP DIs (2009:Q3)

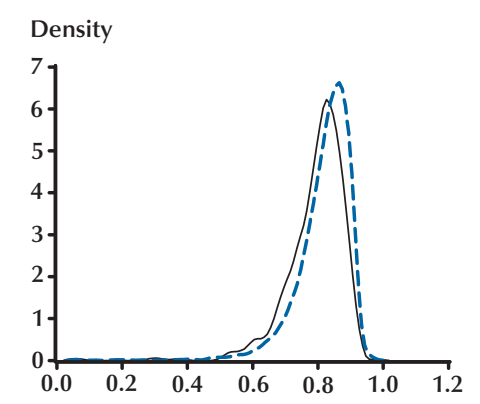

- - Deposits-to-Assets Ratio of All Non-CPP DIs

- Deposits-to-Assets Ratio of All CPP DIs

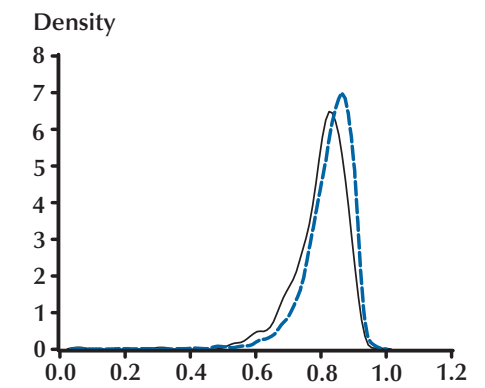

- - Deposits-to-Assets Ratio of Non-CPP Banks

- Deposits-to-Assets Ratio of CPP Banks

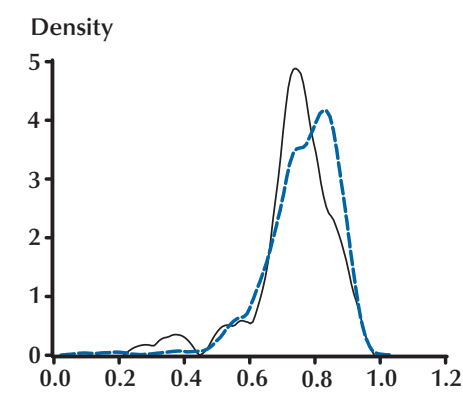

- - Deposits-to-Assets Ratio of Non-CPP Thrifts

- Deposits-to-Assets Ratio of CPP Thrifts

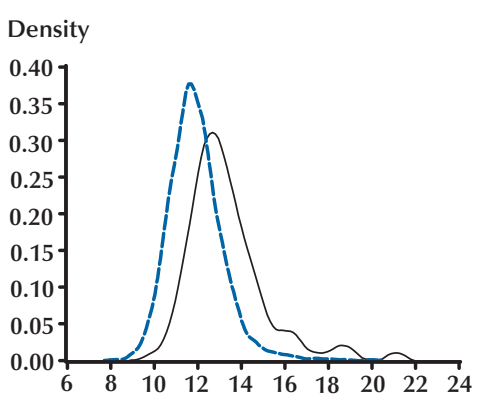

- - Log Assets of All Non-CPP DIs — Log Assets of All CPP DIs

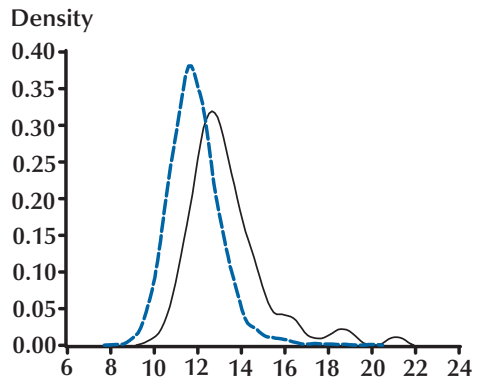

- - Log Assets of Non-CPP Banks - Log Assets of CPP Banks

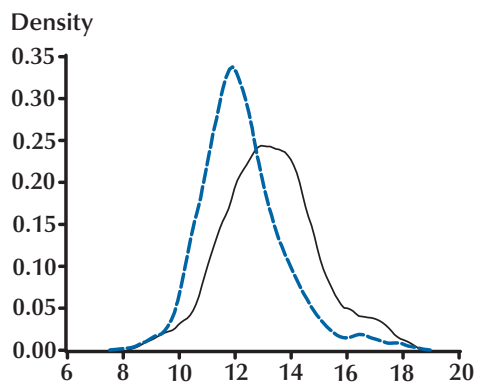

- - Log Assets of Non-CPP Thrifts - Log Assets of CPP Thrifts

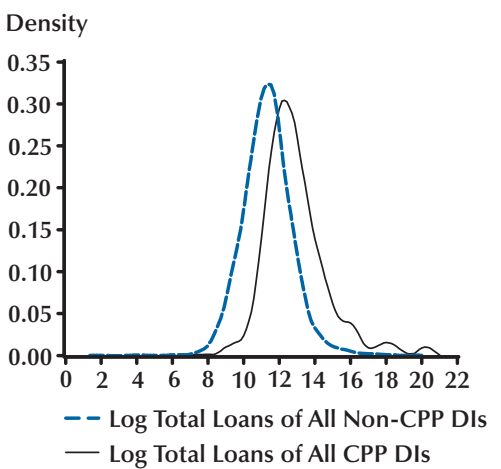

Density

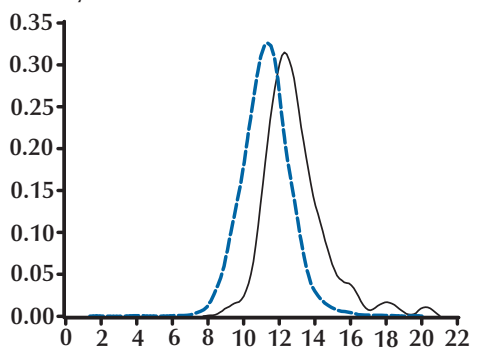

- - Log Total Loans of Non-CPP Banks - Log Total Loans of CPP Banks

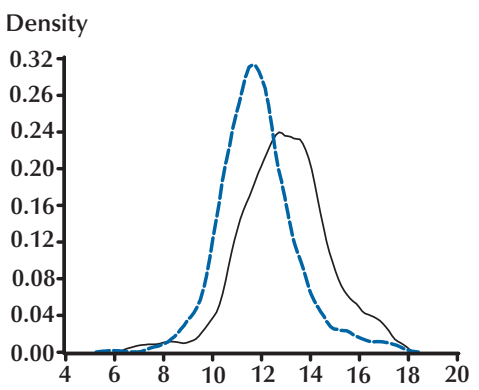

- - Log Total Loans of Non-CPP Thrifts - Log Total Loans of CPP Thrifts

SOURCE: Authors' calculations based on CRs, TFRs, and Treasury data. 
the CRs and TFRs) into a consolidated entity according to a procedure discussed in the appendix. In our data, 28 CPP "multi-unit” beneficiaries control 110 banks and thrifts.

Tables 1 (all DIs) and 2 (banks and thrifts separately) and Figure 4 summarize some relevant variables and ratios. They distinguish between institutions that received CPP funding and those that did not and use the entire population of DIs as a term of comparison. Figure 4 considers total assets and total loans, which are measures of bank size, at the end of 2009:Q3. We plot the distribution of CPP and non-CPP banks and thrifts using the logarithm of assets on the horizontal axis. We repeat the same plots for the logarithm of total loans for banks, thrifts, and all DIs and plot a similar distribution for the deposit-to-assets ratio. ${ }^{19}$ Table A1 in the appendix lists variables and correspondence from CRs and TFRs.

Figure 4 uses kernel density plots for banks and thrifts in terms of assets (second column, second and third rows) or total loans (third column, second and third rows) to provide a visual comparison between CPP beneficiaries (solid line) and non-CPP DIs (dashed line). A quick comparison of the graphs shows that banks are larger on average, but there are relatively more small banks than small thrifts. The largest banks in our sample have outstanding loans of about $\$ 740$ billion, which is about 15 times the outstanding loans of the largest thrift. Consistent with the role of thrifts in the U.S. economy, their average real estate loans as a share of total loans are larger than the share of real estate loans extended by banks. On average, banks have lower loans-to-assets ratios, ${ }^{19}$ lower leverage (assets-to-equity ratio), and are more dependent on deposits as a share of total liability plus equity.

The comparison between CPP and non-CPP DIs shows that CPP beneficiaries are larger than non-beneficiaries in terms of total loans and in terms of total assets (on average, about 20 times larger, but this is skewed to some extent by the

\footnotetext{
${ }^{19}$ Summary statistics are calculated before the regrouping of multiunit DIs, which leaves 614 banks and 54 thrifts for a total of 668 CPP beneficiaries. The number of observations is reported in the tables. All variables for banks and thrifts are comparable except for cash.
}

fact that the largest DIs-Citibank, JPMorgan Chase, and Bank of America-received CPP support). CPP DIs extend a slightly larger share of real estate and C\&I loans and have slightly larger leverage and lower deposits-to-assets ratios. These differences characterize both the thrifts and the banks that received CPP funds.

\section{LENDING PATTERNS}

In this section, we describe the methodology used to reconstruct lending patterns and discuss the results obtained from analyzing lending data between 1998:Q1 and 2010:Q2 (inclusive).

\section{Methodology}

Aggregate Stocks. We first reconstruct loan stocks by totaling the loans of the individual banks and thrifts and adjusting for mergers, acquisitions, and failures (see the appendix). We consider four types of loans: total loans, real estate loans, C\&I loans, and loans to consumers. Our aggregate stocks differ from the H.8 data release for reasons discussed extensively in Den Haan, Summer, and Yamashiro $(2003,2007)$ and-with a specific focus on the current crisis-in Contessi and Francis (forthcoming). We cross-checked our series with the aggregate loan data released by the FDIC for thrifts and banks and confirmed a close match between each pair of series. We also reconstruct outstanding loans by bank size, using the top percentile, the top 25 percentiles, and the bottom 75 percentiles of banks and thrifts ranked by total assets. Once we determine the outstanding loans for the population of banks and thrifts, we split the sample into two groupsCPP DIs and non-CPP DIs-depending on whether they received CPP support at any time between the beginning of the program in October 2008 and the end of December 2009.

Outstanding loans by type of loan and size of bank are plotted in the left columns of the graphs in Figures 5 and 6, along with the quarter-toquarter growth rates for these series during the quarters in which the CPP was created and implemented (the right side of each figure). 


\section{Figure 5}

\section{Loans of Commercial Banks and Thrifts by Size of Institutions (2008:Q1-2010:Q2)}

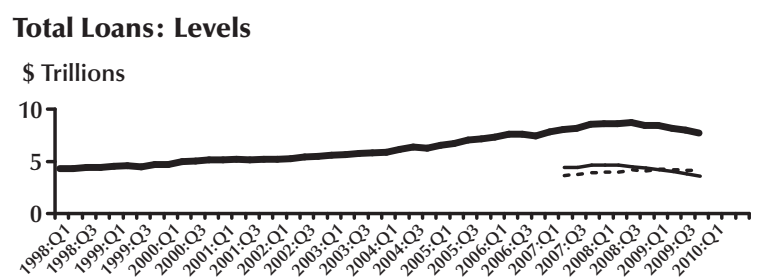

Top 1\% Banks: Levels

\$ Trillions

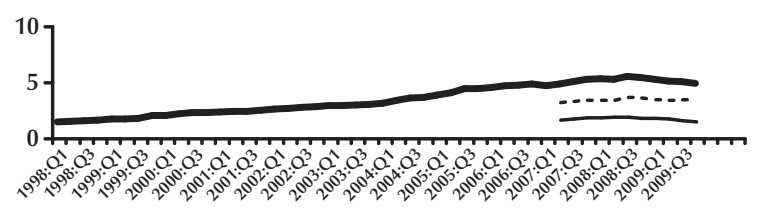

Top 25\% Banks: Levels

\$ Trillions

10
5
0

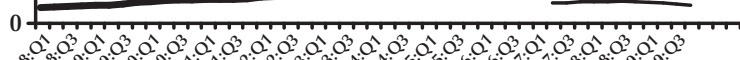

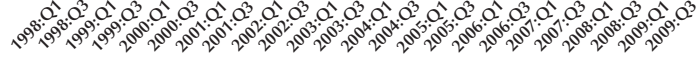

Bottom 75\% Banks: Levels

\$ Trillions

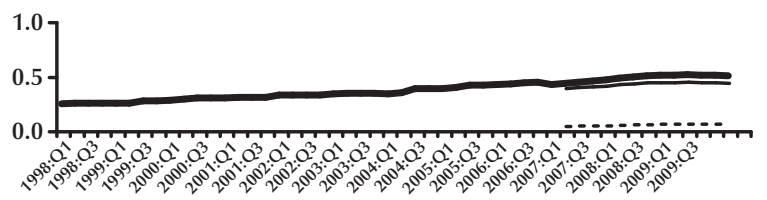

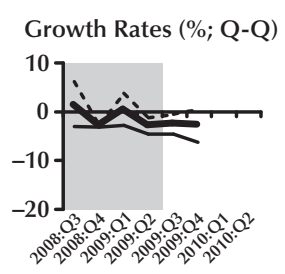

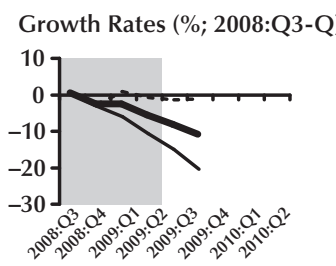

Growth Rates (\%; Q-Q)

Growth Rates (\%; 2008:Q3-Q)
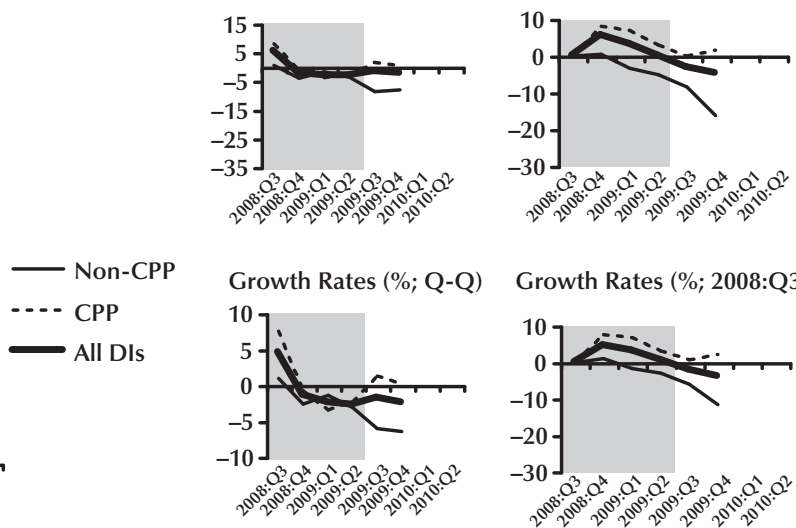

Growth Rates (\%; 2008:Q3-Q)

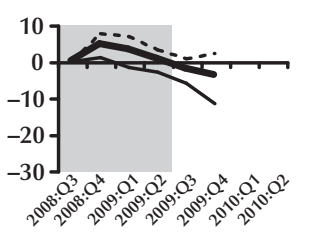

Growth Rates (\%; Q-Q)

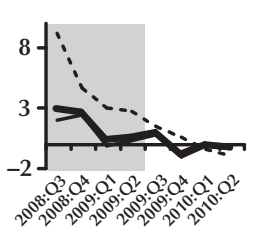

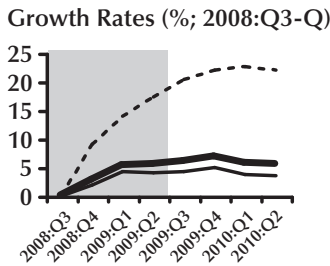

NOTE: Authors' calculations based on CR, TFR, and Treasury data. Q-Q, quarter on quarter; 2008:Q3-Q, between 2008:Q3 and the quarter on the horizontal axis. Gray bars indicate NBER-dated recessions. See text for details.

Nominal Gross Credit Flows. To understand gross credit flows, we begin with a methodology developed by Davis, Haltiwanger, and Schuh (1996) for flows of workers into and out of employment and subsequently adapted to banking flows by Dell'Ariccia and Garibaldi (2005). Figure 7 depicts the relationship between job flows and loan flows. Following Dell'Ariccia and Garibaldi (2005), we create measures of credit expansion and credit contraction to determine measures of gross flows, net flows, and credit reallocation in excess of net credit changes. For each DI, $i$, and period, $t, l_{i, t}$ is the value of nominal loans in one quarter and $\Delta l_{i, t}=l_{i, t}-l_{i, t-1}$ is the change in total loans.

We define "loan creation" as the sum of the change in loans for all DIs that increased their loans since the previous quarter; we define "loan destruction" as the absolute value of the decrease in loans for all DIs that reduced their loan holdings from the previous quarter. In other words, a DI expands credit in a given period if its credit growth is positive and contracts credit in a given period if its credit growth is negative. Then 


\section{Figure 6}

\section{Aggregate Loans and Gross Loan Flows of Commercial Banks and Thrifts by Type of Loan (2008:Q1-2010:Q2)}
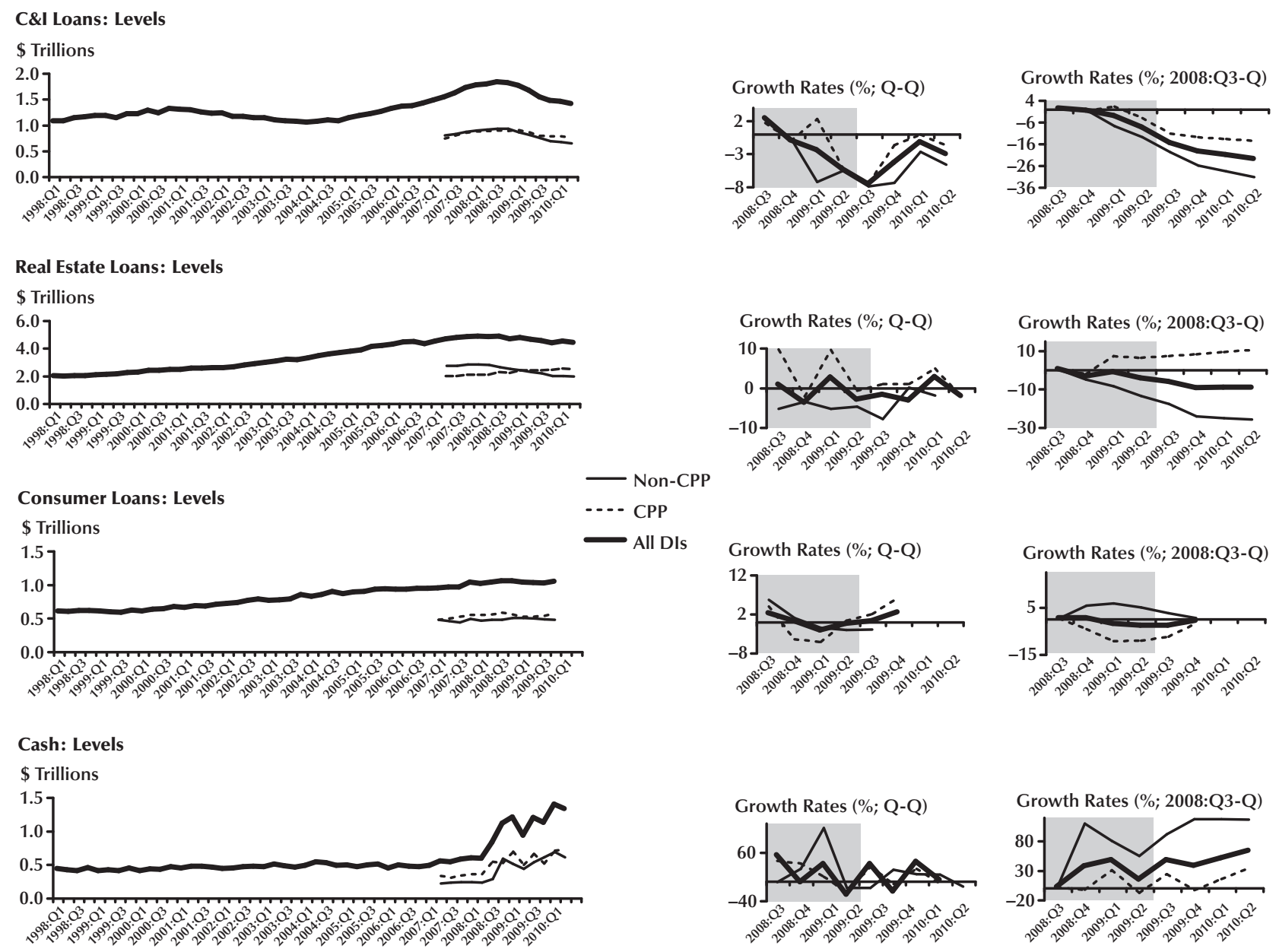

NOTE: Gray bars indicate NBER-dated recessions. See Figure 5 note and text for details.

SOURCE: Authors' calculations based on CR, TFR, and Treasury data.

"gross flows" is the sum of loan creation and loan destruction (whereas "net flows" is the difference between the two).

We reconstruct gross flows as follows. We first compute adjusted credit growth rates $\tilde{g}_{i t}$, defined as $\tilde{g}_{i t}=\tilde{\Delta} l_{i t} /\left[0.5 *\left(l_{i t-1}+l_{i t}\right)\right]$, that is, the ratio between the adjusted change in total loans between $t$ and $t-1\left(\tilde{\Delta} l_{i t}\right)$ and the average value of loans between $t$ and $t-1$, which then bounds the adjusted credit growth rate between -2 and +2 .
Naturally, $\tilde{g}_{i t}$ is positive for the generic bank $i$ if it has expanded loans between $t$ and $t-1$ and is negative in the opposite case. We then aggregate individual adjusted credit growth rates over the share of the population of DIs for which $\tilde{g}_{i t}$ is positive, as follows:

$$
\operatorname{POS}_{t}=\sum_{i \mid \tilde{g}_{i t} \geq 0}^{N} \tilde{g}_{i t}\left(\frac{0.5 *\left(l_{i t-1}+l_{i t}\right)}{\sum_{i=1}^{N} l_{i t-1}}\right)=\frac{\sum_{i \mid \Delta \tilde{I}_{i t} \geq 0}^{N} \Delta \tilde{l}_{i t}}{\sum_{i=1}^{N} l_{i t-1}} .
$$




\section{Figure 7}

\section{Approach to Gross Loan Flows*}
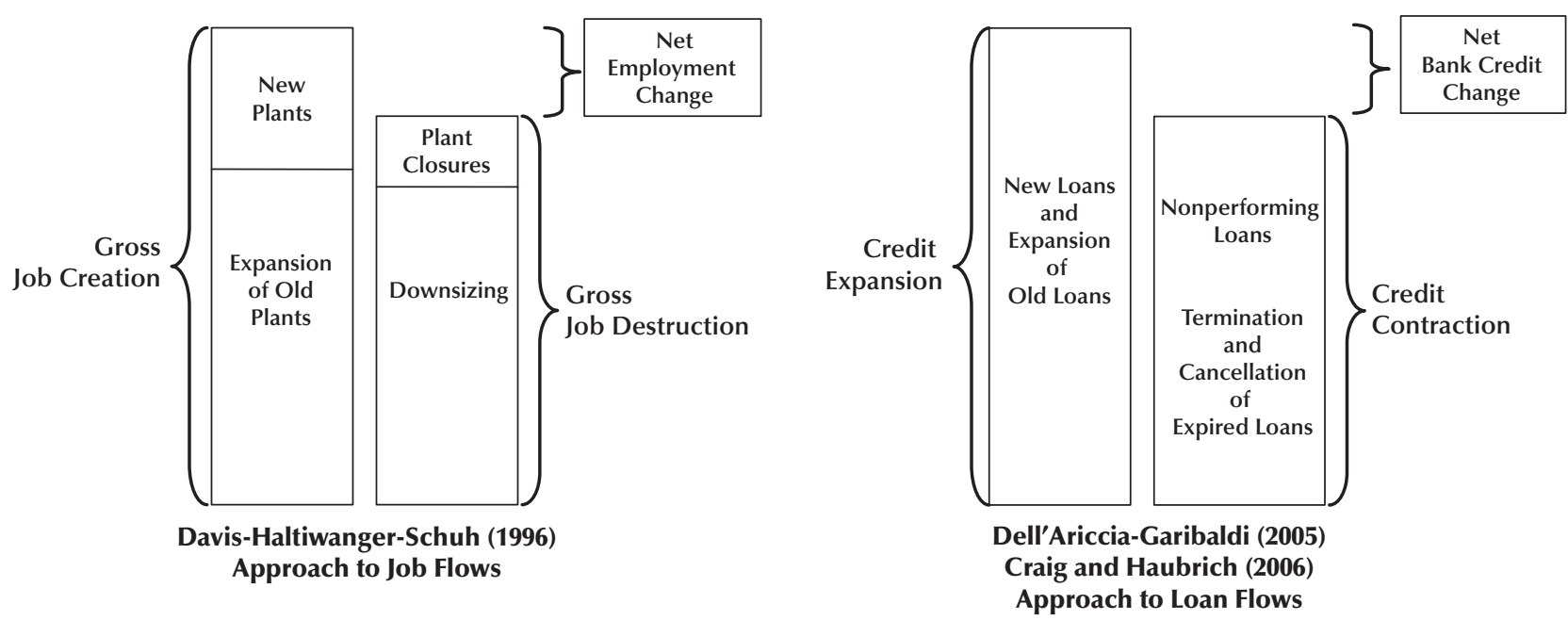

NOTE: *Based on Garibaldi and Dell'Ariccia (2005).

We calculate a similar measure for those DIs that exhibit a decrease in loans $\tilde{g}_{i t}<0$,

$$
N E G_{t}=\sum_{i \mid \tilde{g}_{i t}<0}^{N}\left|\tilde{g}_{i t}\right|\left(\frac{0.5 *\left(l_{i t-1}+l_{i t}\right)}{\sum_{i=1}^{N} l_{i t-1}}\right)=\frac{\sum_{i \mid \Delta \tilde{I}_{i t}<0}^{N} \Delta \tilde{l}_{i t}}{\sum_{i=1}^{N} l_{i t-1}} .
$$

$\mathrm{POS}_{t}$ then becomes a measure of all banks that are expanding lending in a given period, while $N E G_{t}$ is a measure of all banks that are contracting lending in a given period. We split changes in lending across time into these two measures to understand how gross flows have changed over time. Given these two measures of credit expansion $\left(P O S_{t}\right)$ and contraction $\left(N E G_{t}\right)$, we can define the net growth rate of credit as their difference, $N E G_{t}=P O S_{t}-N E G_{t}$, and a measure of reallocation in excess of the net credit change, $E X C_{t}=P O S_{t}+N E G_{t}-\left|N E G_{t}\right|$. We use these measures to discuss nominal flows. A series of adjusted nominal flows can be created in other ways, but we focus on this method as it provides a conservative measure of loan growth and is consistent with other work in this area (see Dell'Ariccia and Garibaldi, 2005, and Contessi and Francis, 2010).

\section{DISCUSSION}

Figures 5 and 6 show graphs of our series for the levels of outstanding loans and the gross flows as previously defined. In these graphs, aggregate stocks of outstanding loans are plotted on the left; their growth rate in the middle; and gross flows, expansion, and contraction on the right. We distinguish among all DIs, DIs that received CPP support at any point in time, and DIs that never received CPP support.

Figure 8 shows the now-clear decline of DI lending, which was dubious at the peak of the crisis (Chari, Christiano, and Kehoe, 2008) but clearly began in the winter of 2008-09 (Contessi and Francis, forthcoming) and continues to date. The graphs on the left plot the level of outstanding loans for all DIs (thick solid line), CPP beneficiaries (solid line), and non-CPP beneficiaries (dotted line). All series show a clear decline during 2009, with some bumpiness in the growth rate graphs in the middle of the figure. If the lending decline was approximately the same for CPP and non-CPP institutions at the end of 2008, it later became much more pronounced for DIs that did not receive funding through the TARP-CPP program. 


\section{Figure 8}

\section{Loans of Commercial Banks and Thrifts by Size of Institutions (2008:Q1-2010:Q2)}
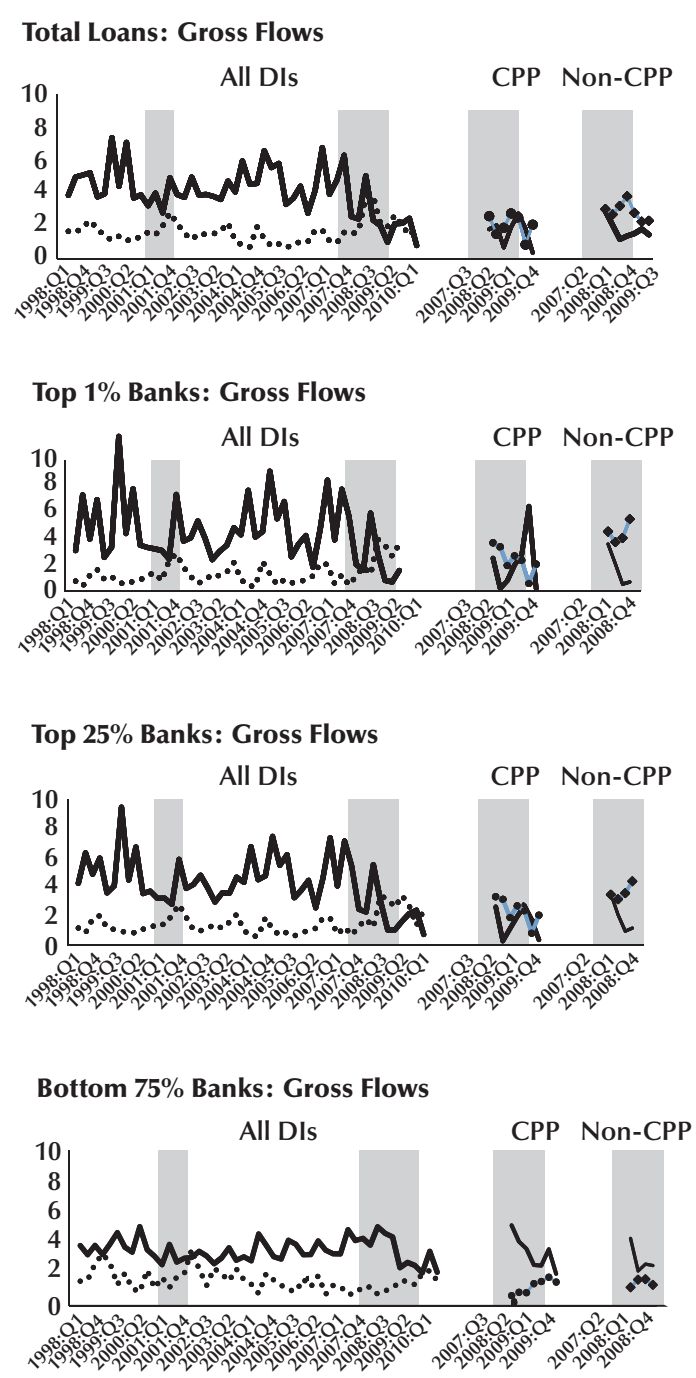

C\&I Loans: Gross Flows

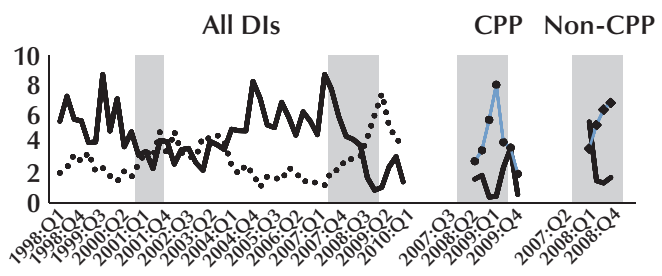

Real Estate Loans: Gross Flows

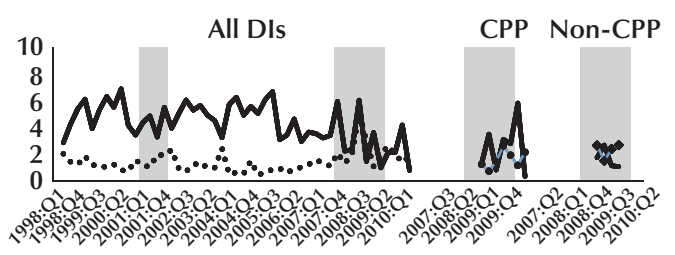

Consumer Loans: Gross Flows

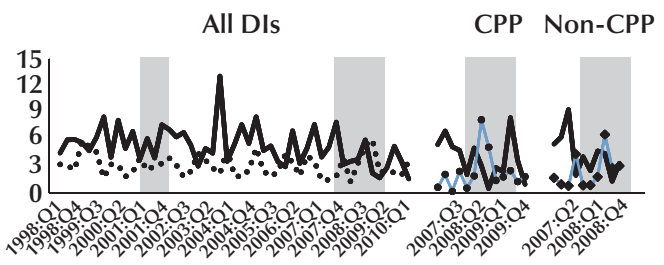

- POS

NOTE: Authors' calculations based on CR, TFR, and Treasury data. Gray bars indicate NBER-dated recessions. See text for details.

It should be emphasized that establishing causality in this context is difficult. The difference in the lending decline between the CPP and non-CPP recipients may not be due to the effects of the CPP but may simply reflect a selection effect. In this context, the selection may affect the observed lending patterns because DIs that were in distress and not likely to benefit from the program were excluded from the CPP and may have experienced a de facto larger lending decline.
Therefore, we caution against making inferences based solely on our series and leave the problem of identifying the effects of selection into treatment to future research. A second noteworthy fact is that CPP institutions had a history of stronger lending expansion that may have affected their propensity to reduce lending less than other banks and thrifts, regardless of the program.

The graphs on the second, third, and fourth rows of Figure 8 illustrate the contribution of 
various groups of DIs to the lending contraction. We identify three groups of banks based on total assets as a proxy for size and regroup the population of more than 8,100 DIs into three quantiles: the largest 80 DIs in the top percentile (second row), the largest 2,080 DIs in the top quartile (third row), and the smallest 6,000 banks (fourth row). Because the size distribution of banks is so skewed to the right, the pattern of aggregate lending is clearly dominated by the larger banks. The growth rates of the banks in the top percentile are quite similar to the growth rates for all banks because these banks are so large that their patterns have a strong effect on the summary statistics. We also note an even more pronounced decline of lending among DIs in the top percentile for the non-CPP DIs than for the entire set of banks.

The fourth-row graph in Figure 8 shows quite clearly that the large majority of small- and medium-sized DIs did not participate in the CPP program either because they did not apply or did not meet the requirements in terms of sufficient financial soundness. Here again, the difference in lending performance of CPP and non-CPP institutions emerges with CCP DIs outperforming non-CPP DIs in terms of lower lending contraction. These graphs also illustrate how the lending contraction from this portion of the credit market was relatively smaller, even if the loan growth rates of these DIs declined to almost zero by the second half of 2009.

Figure 6 distinguishes among three types of loans: real estate loans, C\&I loans, and loans extended to individuals (non-real estate consumer loans). In relative terms, the largest contraction was recorded in C\&I loans, which are more procyclical than other types of loans. ${ }^{20}$ The drop in the stock of these loans is quite dramatic, and the growth rates do not differ much between CPP and non-CPP institutions. Loans extended to individuals also follow a similar pattern for the two groups of DIs, with mildly negative growth rates, particularly at the beginning of 2009.

\footnotetext{
${ }^{20}$ See Contessi and Francis (forthcoming). Note that ordinary banks are no longer the main providers of C\&I loans. Syndicated lending and the commercial paper market provide the majority of such lending. Banks do, however, provide lines of credit that firms can use during times of reduced liquidity in the market.
}

The most interesting difference between DIs that received CPP support and those that did not is for real estate loans. Non-CPP institutions show a steep decline in lending in this category, but DIs that received CPP funding display mildly positive (though close to zero) growth rates. It should be clear that a comparison of these two lending series does not clarify the direction of causality between the CPP program and the general contraction in lending, since the group of non-CPP DIs does not represent an appropriate control group for the supported institutions. ${ }^{21}$ The apparently better performance of CPP beneficiaries may be affected by selection problems.

Now we consider reallocation across institutions, using gross flows plotted in Figure 8 for various types of loans and three classes of banks. The lines that extend back to 1998 plot credit expansion and contraction for all DIs, whereas the shorter lines plot credit flows for CPP banks and non-CPP banks starting in 2007, before the beginning of the financial crisis. The gray bars represent recessions over these years as dated by the National Bureau of Economic Research (NBER).

In observing our gross flows series from a historical perspective, we notice first that there are significant gross flows at any point of the cycle in any of these series-either total loans or loans disaggregated by type and bank size. Second, the coexistence of expansions and contractions in lending growth is observable across loan types and bank sizes. These observations suggest that the large gross flows observed at the aggregate level do not reflect portfolio reallocation across types of loans because sizable flows exist within each category of loans. Finally, the figures show that large gross flows exist for banks of all sizes, so the aggregate flows do not merely reflect the heterogeneous behavior of banks of different sizes.

Consider the quarters of the crisis and focus on the distinction between CPP and non-CPP beneficiaries. If there were a group of banks contracting loans and another group expanding loans

\footnotetext{
${ }^{21}$ A more appropriate term of comparison would be a priori similar banks that did not receive the CPP; see Chang and Contessi (2011).
} 


\section{Figure 9}

\section{Cyclical Component of the Credit Expansion and the Credit Contraction Series for Total Loans around Five Recessions}

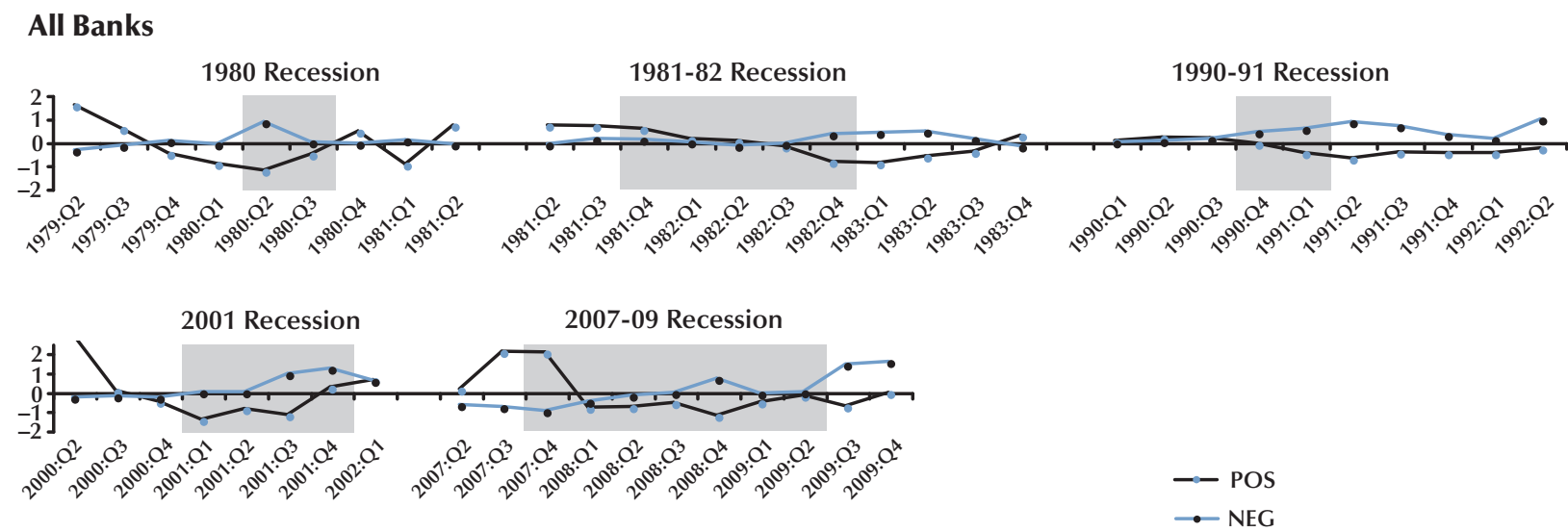

All Banks and Thrifts (CPP vs. Non-CPP)

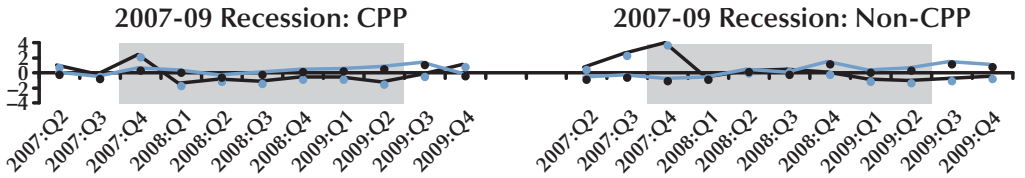

NOTE: The lines are the cyclical components of the levels of credit expansion (POS) and credit contraction (NEG) around NBERdated recessions (gray shading). The trend is identified using the Hodrick-Prescott filter. See text for details.

SOURCE: Authors' calculations based on CR and TFR data.

to take over the customers from these institutions, sharp increases should be observed in both our positive and negative series. Instead, the graphs show essentially no evidence of reallocation between CPP and non-CPP beneficiaries but simply a generalized contraction. Finally, the gross flows series are broadly consistent with our loan stock and growth rate series.

\section{Comparison of Different Recessions}

We examine the behavior of gross credit flows for five recessions for which we recomputed flows for total loans. The current crisis magnifies a general feature of these series: Credit contraction tends to increase during recessions, while credit expansion decreases (Dell'Ariccia and Garibaldi, 2005). For the overall U.S. economy, our estimates show a cross-sectional reduction of net credit only on rare occasions, most notably during and after the 1990-91 recession, an occasion related to the severity of the savings and loan crisis. However, the typical pattern of other recessions, including the 2007-09 recession, is a drop in credit expansion and a sharp increase in credit contraction that generally leave net flow growth positive, albeit small.

Gross bank loan flows behaved similarly over three of the past five recessions (1980, 1981-82, and 2001). However, during the 1990-91 recession gross bank flows behaved quite differently. The start of the current recession appears similar to the start of the 1980 and 2001 recessions, but adding data for 2008 and 2009 makes the pattern more similar to the start of the 1990-91 recession 
(Figure 9). In the 1980 and 1981-82 recessions, net credit followed a V-shaped pattern, with credit expansion falling quickly below trend just before and during the recession and rebounding sharply immediately after the trough in economic activity. Credit contraction followed the opposite pattern, rising quickly above trend and falling sharply after the trough.

In general, the drop in credit expansion and the rise in credit contraction exhibited little persistence in the 1980 and 1981-82 recessions. In the 1990-91 recession, however, the decline in credit expansion and the increase in contraction were persistent, lasting for two years into the recovery (there was also a fair amount of persistence of low expansion and high contraction after the 2001 recession). In part, this change was due to the savings and loan crisis, which began roughly five years before the 1990-91 recession and was not fully resolved until four years later. During this crisis, more than 1,000 U.S. thrift institutions with combined assets of over $\$ 500$ billion (in current dollars) failed (Curry and Shibut, 2000). In the 1990-91 recession, the increase in credit contraction accounted for approximately 50 percent of the reduction in net credit, whereas in previous recessions credit contraction displayed little change in absolute terms.

Figure 9 plots the cyclical components of the levels of credit expansion and credit contraction around NBER-dated recessions. Qualitatively, the cyclical behavior of the credit expansion series during the 2007-09 recession (darker line) appears remarkably similar to those series for the 1981-82 and 1990-91 recessions. During the savings and loan crisis (which ended in 1994), the negative cyclical component of the credit expansion series was large and persisted for several quarters after the end of the recession; the positive cyclical component of the credit contraction series followed a similar pattern. At the time, the increase in credit contraction accounted for most of the negative change in net credit, generating a so-called creditless recovery. Conversely, the cyclical components of the contraction and the expansion series around the 2001 recession display a profile more similar to that of the 1980 recession, when the cyclical component of contraction exceeded the expansion component for only four quarters. During the 1990-91 recession, there was also a large and persistent increase in excess credit reallocation-up to 4.2 percent at the time of the trough in economic activity (1991:Q1) that remained in the 4 percent range through 1992.

The persistent aggregate excess reallocation during the 1990-91 recession may have been driven by changes in the regulatory and market structure of the banking system. During the 2001 recession, by contrast, excess credit reallocation was as high as 6.2 percent at the trough in economic activity (2001:Q4), but it returned to its average in 2002:Q3. In the 2007-09 recession, excess credit reallocation was slightly above average but not as high as during the 2001 recession. Further quarterly data reveal a creditless recovery similar to that following the savings and loan crisis.

\section{CAVEATS}

Our study is subject to various caveats. (i) The diffusion of securitization necessitates caution in interpreting our results: The observed flows may appear as loan expansion simply because they can no longer be redistributed and transformed from regular loans to securities. An even larger credit contraction may have occurred in the nonregulated banking sector without visibly affecting our data on insured banks and thrifts. (ii) Regulated commercial banks provide about one-third of the total credit to firms in the U.S. economy (Feldman and Lueck, 2007). Thus, the fact that we do not observe unusual distress in the regulated banking sector until 2008:Q4 does not imply that firms had easy access to credit before that period. (iii) Our measures of loan activity are likely affected by other programs implemented by the Treasury and the Federal Reserve and may have been quite different without these interventions. (iv) Although we use comprehensive balance-sheet data to determine measures of credit contraction and expansion, we cannot account for cases of expansion and contraction of individual banks within the same quarter. Moreover, our basic measures do not take into account loan commitments. (v) We try to docu- 
ment a series of facts, not explain them. Further research is necessary to understand the causes and consequences of such observations. In particular, we neither analyze the changes in the cost of borrowing, nor do we disentangle demand from supply effects. (vi) Our comparison of the current crisis with previous recessions may be distorted by the many changes over the past 30 years as banks moved beyond their traditional role of providing loans to their customers. Because the Gramm-Leach-Bliley Act of 1999 allowed nonbanking financial institutions to freely merge and compete for loans, our sample is affected by this activity more so than the sample before 1999.

\section{CONCLUSION}

We describe the gross credit lending activity of U.S. commercial banks and thrifts during the crisis that began in 2007. Our analysis focuses on the distinction between the Capital Purchase Program (CPP) and non-CPP beneficiaries during the financial crisis, which we introduce after creating a novel database that matches CPP data released by the U.S. Treasury with the Call Reports for commercial banks and the Thrift Financial Reports for savings and loan institutions.

Because of the small number of data points (only the four quarters since the CPP was introduced), we cannot formally test for differences in lending behavior. However, we show that the depository institutions that received CPP assistance exhibited less lending contraction than non-CPP beneficiaries. We emphasize that the better performance of CPP beneficiaries may be due to any combination of the following factors: (i) the fact that the CPP actually slowed the decline in lending, (ii) a selection problem that cannot be addressed in our study but which we attempt to analyze in related research, and (iii) the fact that what appears as relatively larger lending growth (or lower lending decline) masks a postponement of bad loan write-downs.

\section{REFERENCES}

Aubuchon, Craig P. and Wheelock, David C. "The Geographic Distribution and Characteristics of U.S. Bank Failures, 2007-2010: Do Bank Failures Still Reflect Local Economic Conditions?” Federal Reserve Bank of St. Louis Review, September/October 2010, 92(5), pp. 395-415;

http://research.stlouisfed.org/publications/review/10/09/Aubuchon.pdf.

Avery, Robert B. and Samolyk, Katherine A. "Bank Consolidation and Small Business Lending: The Role of Community Banks.” Journal of Financial Services Research, April 2004, 25(2), pp. 291-325.

Cebenoyan, A. Sinan and Strahan, Philip E. "Risk Management, Capital Structure and Lending at Banks." Journal of Banking and Finance, 2004, 28(1), pp. 19-43.

Chang, Su-Hsin and Contessi, Silvio. "Capital Injections and Lending Contractions: Evidence from the TARP." Unpublished manuscript, Federal Reserve Bank of St. Louis, 2011.

Chari, Varadarajan V.; Christiano, Lawrence J. and Kehoe, Patrick J. "Facts and Myths about the Financial Crisis of 2008." Working Paper No. 666, Federal Reserve Bank of Minneapolis, October 2008;

www.minneapolisfed.org/research/wp/wp666.pdf.

Coates, John C. and Scharfstein, David S. “The Bailout Is Robbing the Banks.” New York Times, February 17, 2009; www.nytimes.com/2009/02/18/opinion/18scharfstein.html.

Congressional Oversight Panel. "February Oversight Report. Valuing Treasury's Acquisitions.” February 6, 2009, http://cop.senate.gov/documents/cop-020609-report.pdf. 


\section{Contessi and Francis}

Contessi, Silvio and Johanna Francis. "U.S. Commercial Bank Lending through 2008:Q4: New Evidence from Gross Credit Flows.” Economic Inquiry (forthcoming); preview at http://onlinelibrary.wiley.com/doi/10.1111/j.1465-7295.2010.00356.x/pdf.

Curry, Timothy and Shibut, Lynn. "The Cost of the Savings and Loan Crisis: Truth and Consequences." FDIC Banking Review, 2000, 13(2), pp. 26-35; www.fdic.gov/bank/analytical/banking/2000dec/brv13n2 2.pdf.

Davis, Steven J.; Haltiwanger, John C. and Schuh, Scott. Job Creation and Destruction. Cambridge, MA: MIT Press, 1996.

Dell'Ariccia, Giovanni and Garibaldi, Pietro. “Gross Credit Flows.” Review of Economic Studies, July 2005, 72(3), pp. 665-85.

Den Haan, Wouter J.; Sumner, Steven W. and Yamashiro, Guy M. "Data Manual for Bank Loan Portfolios and the Monetary Transmission Mechanism.” Unpublished manuscript, University of San Diego, 2003.

Den Haan, Wouter J.; Sumner, Steven W. and Yamashiro, Guy M. "Bank Loan Portfolios and the Monetary Transmission Mechanism.” Journal of Monetary Economics, April 2007, 54(3), pp. 904-24.

El-Ghazaly, Hoda and Gopalan, Yadav. “A Jump in Consumer Loans?” Federal Reserve Bank of St. Louis Economic Synopses No. 18, July 1, 2010; http://research.stlouisfed.org/publications/es/10/ES1018.pdf.

Feldman, Ron J. and Lueck, Mark. "Are Banks Really Dying This Time? An Update of Boyd and Gertler.” Federal Reserve Bank of Minneapolis The Region, September 2007, pp. 6-9, 42-51; www.minneapolisfed.org/publications papers/pub display.cfm?id=1139.

Hoshi, Takeo and Kashyap, Anil K. "Will the U.S. Bank Recapitalization Succeed? Eight Lessons from Japan." Journal of Financial Economics, September 2010, 97(3), pp. 398-417.

Kishan, Ruby P. and Opiela, Timothy P. "Bank Capital and Loan Asymmetry in the Transmission of Monetary Policy.” Journal of Banking and Finance, January 2006, 30(1), pp. 259-85.

Lown, Cara; Peristiani, Stavros and Robinson, Kenneth J. "Financial Sector Weakness and the M2 Velocity Puzzle.” Economic Inquiry, October 2006, 44(4), pp. 699-715.

Special Inspector General for the Troubled Asset Relief Program (SIGTARP). "Emergency Capital Injections Provided to Support the Viability of Bank of America, Other Major Banks, and the U.S. Financial System." Office of Special Inspector General for the Troubled Asset Relief Program, Audit of October 5, 2009a; www.sigtarp.gov/reports/audit/2009/Emergency Capital Injections Provided to Support the Viability of Bank of America... 100509.pdf.

Special Inspector General for the Troubled Asset Relief Program (SIGTARP). "SIGTARP Survey Demonstrates that Banks Can Provide Meaningful Information on Their Use of TARP Funds.” Office of Special Inspector General for the Troubled Asset Relief Program, Report of July 20, 2009b; www.sigtarp.gov/reports/audit/2009/SIGTARP Survey Demonstrates That Banks Can Provide Meaningful Information On Their Use Of TARP Funds.pdf.

U.S. Treasury. "Troubled Asset Relief Program Transaction Report for the Period Ending November 25, 2009." U.S. Department of Treasury, November 25, 2009. 


\section{APPENDIX}

\section{Mergers and Acquisitions}

To aggregate our data from individual CRs and TFRs, we need to correct loan flows for mergers and acquisitions. For example, if depository institution (DI) $i$ (the surviving bank) acquires DI $j$ (the non-surviving bank or thrift) in period $t$, then the loan portfolio for DI $j$ is zero or $l_{j, t}=0$, while the loan portfolio for the surviving DI includes the previous balances of the acquired DI plus its net loan changes, or $\Delta l_{i, t}=l_{i, t-1}+\Delta l_{i, t}+l_{j, t-1}+\Delta l_{j, t-1}$. Thus, we need to adjust the change in DI $i$ 's loans by subtracting the loans of DI $j$ in $t-1$ from the change in DI $i$ 's loans and add them to the difference for DI $j$. The adjusted change in the loan portfolios should then be

$$
\tilde{\Delta} l_{i, t}=\Delta l_{i, t}-\sum_{k=1}^{N} \varphi_{i k}(t) l_{k, t-1}-\psi_{i}(t) \Delta l_{i, t}
$$

where $\varphi_{i k}(t)$ is an indicator function that takes a value of 1 if DI $i$ acquires DI $k$ between $t-1$ and $t$ and the value 0 otherwise. Thus, if DI $k$ is acquired by DI $i$, its loans from the previous period are subtracted from the raw change in DI $i$ 's loan portfolio. Similarly, $\psi_{i}(t)$ is an indicator function-that is, its value is 1 if DI $i$ is itself acquired (by some other DI) between period $t-1$ and $t$. Thus, we keep the changes in an acquired DI's loan portfolio with the acquired bank for the period of acquisition and remove them from the acquiring DI. There are two exceptions to this rule: If the non-surviving DI was divided among several DIs, unless we could otherwise determine what share of the loans the acquiring DIs received, we divided the changes in lending of the acquired DI by the number of acquiring DIs and removed part of the new credit from each of the acquiring DIs. The second exception involves the original bank's survival of a merger or acquisition (i.e., the original bank keeps its own charter); in that case, we leave all the changes in credit with the original DI and none with the newly formed DI.

We used data from the National Information Center to identify the dates when DIs experienced a transformation-for example, a merger or acquisition (either as the acquirer or acquiree) with discontinuation of one of the involved entities' charter, a split, sale of assets, merger without a charter discontinuation, or a failure. These data were matched with CR and TFR data on bank balance sheets and used to adjust loan totals (and subcategories of loans).

\section{Table A1}

\section{Variables List and Correspondence from CRs and TFRs}

Call Reports

rcfd2170 Total assets

rcfd2200 Total deposits

rcfd1410 Real estate loans

rcfd1766 Commercial and industrial loans - Other

rcfd1975 Loans to individuals

rcfd0010 Cash

rcfd3210 Equity
Thrift Financial Reports

svgl2170 Total assets (SC60)

svgl2339 Deposits and escrows: Total (SC71)

svgl0446 Mortgage loans (SC26)

svgl0655 Commercial loans: Total (SC32)

svgl0656 Consumer loans: Total (SC35)

svgl0626 Cash and non-interest-earning

deposits (SC110)

svgl3491 Total equity capital (SC84)

rcfd3815 Credit card lines, unused commitments

rcfd3814 Revolving, open-end lines secured by 1-4 residential properties, unused commitments

rcfd3423 Unused commitments, total 
